\title{
Experimental Trial with a Heat-Shocked Protoscolex Extract as a Vaccine Candidate for Protection Against Hydatid Disease
}

\author{
Kist Hidatik Hastalığına Karşı Koruma İçin Aşı Adayı Olarak Isıl Şoklanmış Protoskoleks \\ Ekstrakt İle Deneysel Çalışma
}

\author{
Husain Hassan', Tariq S. AL-Hadithi', Hadi M Al-Sakee ${ }^{1}$ \\ 'Department of Biology, College of Science, Kirkuk, Iraq
}

\section{ABSTRACT}

Objective: Cystic echinococcosis is distributed worldwide and is an important public health challenge in many countries. The present study was an experimental trial to use hydatid antigens derived from viable protoscoleces cultivated at 37 and $45^{\circ} \mathrm{C}$ for $4 \mathrm{~h}$ as a vaccine candidate for protection against hydatid infection.

Methods: Balb/c mice were immunized with hydatid antigens extracted from protoscoleces exposed to 37 and $45^{\circ} \mathrm{C}$ as well as partially purified hydatid antigens containing 30,60 , and $90 \mu \mathrm{g}$ of heat shock protein 70 administered with or without an adjuvant.

Results: Crude antigens from protoscoleces exposed to $37^{\circ} \mathrm{C}$ conferred non-significant immunity with protection and reduction rates that ranged from $0 \%$ to $25 \%$ and $77.69 \%$ to $98.38 \%$, respectively. In mice receiving crude antigens from protoscoleces exposed to $45^{\circ} \mathrm{C}$, the protection and reduction rates ranged from $0 \%$ to $66.66 \%$ and $94.62 \%$ to $98.92 \%$, respectively. The purified antigen from protoscoleces exposed to $45^{\circ} \mathrm{C}$ conferred significant immunity with absolute protection observed in mice immunized with 60 and $90 \mu \mathrm{g}$ of the antigen combined with the adjuvant. Immunological parameters (anti-hydatid antibody titer and lymphocyte transformation \%) showed a negative correlation with the number of cysts. The assessment of renal and liver functions showed non-significant differences ( $p>0.05)$ in comparison with the liver and renal functions of non-immunized mice of the negative control group.

Conclusion: Purified hydatid antigens containing heat shock protein 70 confer high levels of protection against hydatid infection in mice (Turkiye Parazitol Derg 2016; 40: 1-8).

Keywords: Heat shock protein, Protoscoleces, Hydatid disease.

Received: 12.11 .2014

Accepted: 06.02.2016

\section{ÖZ}

Amaç: Kistik ekinokokkoz tüm dünyada yayılmaktadır ve birçok ülkede görülen önemli bir halk sağlığı problemidir. Bu çalışma hidatik kist enfeksiyonuna karşı bir aşı adayı olarak, 37 ve $45^{\circ} \mathrm{C}^{\prime}$ de 4 saatte üretilen canlı protoskolekslerden türemiş hidatik antijenler kullanılarak yapılan deneysel bir çalışmadır.

Yöntemler: Balb/c fareler, bir adjuvanla ya da adjuvansız uygulanan ısıl şoklanmış 30, 60 ve $90 \mu \mathrm{g}$ protein 70 içeren kısmen purifiye hidatik kist antijenlerinin yanı sıra, 37 ve $45^{\circ} \mathrm{C}^{\prime}$ ye maruz kalmış protoskolekslerden elde edilen hidatik antijenlerle immünize edildiler.

Bulgular: $37^{\circ} \mathrm{C}^{\prime}$ ye maruz kalmış protoskolekslerden elde edilen ham antijenlerle, koruma ile anlamlı olmayan immünite ve sırasıyla \%0 ile \%25 ve $\% 77,69$ ile \%98,38 arasında değişen azalma oranları ortaya konuldu. $45^{\circ} \mathrm{C}^{\prime}$ ye maruz kalmış protoskolekslerden elde edilen ham antijenler verilen farelerde, koruma ve azalma oranları sırasıyla \%0 ile \%66,66 ve \%94,62 ile \%98,92 arasında değişiklik gösterdi. $45^{\circ} \mathrm{C}^{\prime}$ ye maruz kalan protoskolekslerden elde edilen purifiye (saflaştııımış) antijen, adjuvan ile kombine 60 ve $90 \mu \mathrm{g}$ antijenle immunize edilmiş farelerde gözlenen mutlak koruma ile birlikte anlamlı bir immünite ortaya koymuştur. İmmünolojik parametreler (anti-hidatik kist antikor titresi ve lenfosit transformasyon \%) kist sayıs ile negatif bir korelasyon göstermiş̧ir. Negatif kontrol grubundaki immünize olmamış farelerin karaciğer ve böbrek fonksiyonları ile kıyaslandığında, böbrek ve karaciğer fonksiyonlarının değerlendirilmesinde anlamlı olmayan farklılıklar bulunmuştur ( $p>0,05)$.

Sonuç: Isıl şoklanmış protein 70 içeren purifiye hidatik antijenler, farelerde hidatik kist enfeksiyonuna karşı koruma sağlamaktadırlar. (Turkiye Parazitol Derg 2016; 40: 1-8)

Anahtar Kelimeler: Isıl şoklanmış protein, Protoskoleks, Hidatik kist hastalığı.

Geliş Tarihi: 12.11.2014

Kabul Tarihi: 06.02.2016

Address for Correspondence / Yazışma Adresi: Dr. Husain Hassan. E.mail: husain758@yahoo.com DOI: 10.5152/tpd.2016.3993

CCopyright 2016 Turkish Society for Parasitology - Available online at www.tparazitolderg.org

CTelif hakkı 2016 Türkiye Parazitoloji Derneği - Makale metnine www.tparazitolderg.org web sayfasından ulaşılabilir. 


\section{INTRODUCTION}

Cystic echinococcosis is distributed worldwide and is an important public health challenge in many countries (1-6). In Iraq, the disease is regarded as one of the most important public health and socioeconomic problems (7-9).

In endemic areas, serious steps should be taken toward to prevent and control the disease, including the designing of studies focusing on the development of vaccine candidates derived from parasite tissues. In Iraq, many studies have been conducted in this field, most of which have tried to use attenuated protoscoleces (10-11). Other investigators have tried to use excretory/ secretory antigens or antigens derived from hydatid fluid as vaccine candidates for protection against hydatid disease (12).

Recently, heat shock proteins, which are a family of proteins expressed in all living cells when exposed to stressful conditions such as high temperature, irradiation, and infection, have attracted the attention of immunologists (13-17). These proteins have been found to function as molecular chaperones, preventing the stress-induced aggregation of partially denatured proteins and promoting their return to the native conformation (18-19). Currently, there is a great deal of interest in developing vaccines using heat shock protein fusion proteins that would generate powerful immune responses in the absence of adjuvants $(4,16,20)$. This research was conducted to study the immunogenicity of hydatid antigens derived from heat-shocked protoscoleces and the possibility of using such antigens as vaccine candidates for providing immunity against hydatid infection.

\section{METHODS}

In vitro cultivation of protoscoleces for the expression of heat shock protein 70

The procedure described by Martinez et al. (21) was followed. Briefly, protoscoleces were aseptically collected from the infected livers of sheep slaughtered in a slaughterhouse in Erbil. The viability of the protoscoleces was assessed prior to cultivation by methylene blue exclusion and flame cell biting. Only those batches of protoscoleces with $95 \%-99 \%$ viability were subjected to cultivation. Two batches of 25000 protoscoleces per $3 \mathrm{~mL}$ of medium 199 (HIMEDIA, India) were separately incubated at 37 and $45^{\circ} \mathrm{C}$ for $4 \mathrm{~h}$. At the end of the incubation, the medium was removed and the precipitated heat-shocked protoscoleces were washed three times with cold PBS (0.15 M; pH 7.2) and stored at $-70^{\circ} \mathrm{C}$ until further use.

A protoscolex extract solution was prepared as described by Seyyedi et al. (22). Heat-shocked $\left(37\right.$ or $45^{\circ} \mathrm{C}$ ) protoscoleces were thawed and washed three times with cold PBS $(0.15 \mathrm{M} ; \mathrm{pH}$ 7.2). Protoscoleces in three volumes of homogenizing buffer $[10 \mathrm{mM}$ EDTA, $2 \mathrm{mM}$ phenylmethylsulfonyl fluoride (Sigma), $0.15 \mathrm{M}$ $\mathrm{NaCL}$, and $50 \mathrm{mM}$ Tris; $\mathrm{pH}$ 7.5] containing 0.5\% (v/v) Triton X-100 were freeze-thawed in three cycles of $10 \mathrm{~min}$ in liquid nitrogen followed by $10 \mathrm{~min}$ in a water bath at $37^{\circ} \mathrm{C}$; they were then homogenized by a homogenizer in an ice bath, and finally, the homogenized protoscoleces were disintegrated by a sonicator. The homogenized and sonicated protoscoleces were then centrifuged at $5000 \mathrm{~g}$ for $30 \mathrm{~min}$ at $4^{\circ} \mathrm{C}$. The supernatant (preparation $1,37^{\circ} \mathrm{C}, 1,45^{\circ} \mathrm{C}$ ) was then aliquoted and stored at $-70^{\circ} \mathrm{C}$ until further use as a crude vaccine preparation.
Partial purification of hydatid antigens containing heat shock protein 70 by column chromatography

A Sephadex G-150 column $(1.5 \times 45 \mathrm{~cm}$; Pharmacia Fine Chemicals) was prepared as described by Hotzhaner (23). After the gel settled, the column was eluted with 4-fold PBS at pH 7.4. The protoscolex extract solution (crude preparation $1,45^{\circ} \mathrm{C}$ ) was run through the column and eluted with PBS $\left(\mathrm{pH} \mathrm{7.4)}\right.$ at $4^{\circ} \mathrm{C}$. Fractions of $3 \mathrm{~mL}$ of eluted fractions were collected in sterile cupped plastic tubes. The optical density of each fraction was recorded by a digital spectrophotometer at a wavelength of 280 $\mathrm{nm}$. The fractions were then aliquoted, labeled, and stored at $-70^{\circ} \mathrm{C}$ until further use.

\section{Detection of heat shock protein 70 in the column chromatograph, eluted fractions}

An indirect hemagglutination test (IHT) as described by other workers (24) was performed for the detection of heat shock protein 70 in the eluted fractions. The eluted fractions that gave absorbance at $280 \mathrm{~nm}$ UV spectrophotometer were adsorbed on sheep red blood cells as a source of heat shock protein 70 antigens and were detected by monoclonal anti-heat shock protein 70 (Sigma, USA). The fractions that gave positive reactions for heat shock protein 70 were used as purified hydatid antigens containing heat shock protein 70 (preparation $2,45^{\circ} \mathrm{C}$ ). The protein content in the extract solutions was determined by the method described by Lowry et al. (25).

\section{Immunization protocol}

Balb/c mice, males and females aged 6-8 weeks with body weight ranging between 18.5 and $27.5 \mathrm{~g}$, were used for the immunization experiments. The immunization protocol was conducted as described by others (26). Briefly, in experiment 1, three groups each of 12 mice were subcutaneously injected with 0.1 $\mathrm{mL}$ of normal saline $(0.85 \%)$ containing 30,60 , or $90 \mu \mathrm{g}$ of preparation $1\left(37^{\circ} \mathrm{C}\right)$ mixed with $0.1 \mathrm{~mL}$ of Freund's complete adjuvant (FCA) for the first immunization. The second immunization was conducted after 4 weeks with the same preparation, with the only difference being that the FCA adjuvant was replaced by Freund's incomplete adjuvant (FIA). Further, three groups of 12 mice each were subcutaneously injected with $0.2 \mathrm{~mL}$ of normal saline containing 30,60 , or $90 \mu \mathrm{g}$ of preparation $1\left(37^{\circ} \mathrm{C}\right)$ without the adjuvant for both immunization protocols.

In experiments 2 and 3 , the protocol above is repeated with the preparations $1\left(45^{\circ} \mathrm{C}\right)$ and $2\left(45^{\circ} \mathrm{C}\right)$, respectively.

\section{Control groups}

1. Adjuvant control: A group of 12 mice were subcutaneously injected with $0.1 \mathrm{~mL}$ normal saline mixed with $0.1 \mathrm{~mL}$ of FCA for the first immunization. The second immunization was conducted after 4 weeks with same preparation, with the only difference being that FCA was replaced by FIA.

2. Positive control: A group of 12 mice were subcutaneously injected with $0.2 \mathrm{~mL}$ of normal saline for both immunization protocols. After 4 weeks, the mice were intraperitoneally challenged with 2000 protoscoleces.

3. Negative control: A group of 12 mice were subcutaneously injected with $0.2 \mathrm{~mL}$ of normal saline for both immunization protocols. 
Four weeks after the last immunization, blood samples were collected by cardiac puncture from 4-5 mice of each group; then, all groups, except the negative control group, were intraperitoneally injected with $0.2 \mathrm{~mL}$ of normal saline containing 2000 protoscoleces as described by Dematteis et al. (27). All mice were killed 90 days after the administration of the challenge dose. The internal organs were examined for secondary hydatid cysts. The site and number of cysts were determined, and the size of each cyst was measured using a ruler. Infected organs and cysts were fixed in formal saline (10\%) for histopathological examinations.

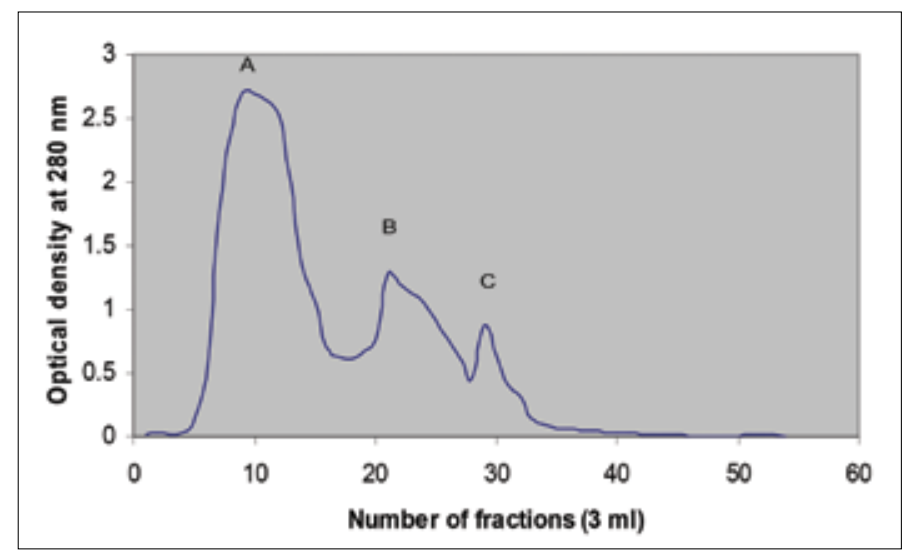

Figure 1. Elution pattern of extracts of $45^{\circ} \mathrm{C}$ treated protoscoleces, passed through Sephadex G-150 column $(1.5 \times 45 \mathrm{~cm})$.

\section{Immunological parameters}

A- The lymphocyte transformation test (LTT) was performed as described by Shubber et al. (28).

B-IHT was performed for the detection of anti-hydatid antibodies in the sera of mice. The procedure described by Parija and Ananthakrishnan (24) was followed.

\section{Assessment of liver and renal functions}

Commercial kits from Biolabo Reagents (France) were used for the determination of liver-related enzyme, alanine aminotransaminase, and aspartate aminotransaminase activities in the sera of experimental mice. Renal function was assessed by the estimation of blood urea levels using a commercial kit provided by bioMerieux (France).

\section{Statistical analysis}

Student's t-test was used for the comparison of the number and size of cysts between the positive control and immunized groups. The correlation coefficient ( $r$ ) was calculated between immunological parameters and number of cysts. Reduction and protection rates were calculated as described by Piacenza et al. (29). $P \leq 0.05$ was considered to be statistically significant.

\section{RESULTS}

\section{Partial purification of heat shock protein 70}

The chromatography pattern of hydatid antigens derived from protoscoleces exposed to $45^{\circ} \mathrm{C}$ is shown in Figure 1, in which three protein peaks (A, B, and C) are observed. Peaks A (frac-

Table 1. Reduction rate of secondary hydatid cysts, protection rate, number and size of cysts in mice immunized with hydatid antigens derived from protoscoleces exposed to $37 \mathrm{C}^{\circ}$ for 4 hours.

\begin{tabular}{|c|c|c|c|c|c|c|}
\hline $\begin{array}{l}\text { Experimental } \\
\text { groups }\end{array}$ & No. of mice & $\begin{array}{c}\text { No. of infected } \\
\text { mice }\end{array}$ & $\begin{array}{l}\text { No. of cysts } \\
\text { (Mean } \pm \text { SD) }\end{array}$ & $\begin{array}{l}\text { Mean of cyst } \\
\text { size } \pm S D(m m)\end{array}$ & $\begin{array}{l}\text { Protection } \\
(\%)\end{array}$ & $\begin{array}{c}\text { Reduction } \\
\text { of cysts (\%) }\end{array}$ \\
\hline $\begin{array}{l}\text { Immunized with } \\
30 \mu g \text { plus } \\
\text { adjuvant }\end{array}$ & 4 & 4 & $\begin{array}{c}83 \\
(20.75 \pm 15.33) \\
(p<0.05)\end{array}$ & $\begin{array}{l}0.77 \pm 0.8 \\
(p<0.01)\end{array}$ & 0 & 77.69 \\
\hline $\begin{array}{l}\text { Immunized with } \\
60 \mu g \text { plus } \\
\text { adjuvant }\end{array}$ & 4 & 3 & $\begin{array}{c}10 \\
(2.5 \pm 1.91) \\
(p<0.05)\end{array}$ & $\begin{array}{c}0.67 \pm 1.2 \\
\text { NS }\end{array}$ & 25 & 97.3 \\
\hline $\begin{array}{l}\text { Immunized with } \\
90 \mu g \text { plus } \\
\text { adjuvant }\end{array}$ & 4 & 3 & $\begin{array}{c}24 \\
(6 \pm 6.37) \\
(p<0.05)\end{array}$ & $\begin{array}{c}0.86 \pm 0.84 \\
(p<0.01)\end{array}$ & 25 & 93.54 \\
\hline $\begin{array}{l}\text { Immunized with } \\
30 \mu \mathrm{g}\end{array}$ & 6 & 6 & $\begin{array}{c}9 \\
(1.5 \pm 0.54) \\
(p<0.05) \\
\end{array}$ & $\begin{array}{c}0.1 \pm 0 \\
(p<0.01)\end{array}$ & 0 & 98.38 \\
\hline $\begin{array}{l}\text { Immunized with } \\
60 \mathrm{\mu g}\end{array}$ & 7 & 6 & $\begin{array}{c}16 \\
(4 \pm 2.29) \\
(p<0.05) \\
\end{array}$ & $\begin{array}{c}0.28 \pm 0.3 \\
\text { NS }\end{array}$ & 14.28 & 95.69 \\
\hline $\begin{array}{l}\text { Immunized with } \\
90 \mu \mathrm{g}\end{array}$ & 5 & 4 & $\begin{array}{c}11 \\
(2.2 \pm 1.92) \\
(p<0.05)\end{array}$ & $\begin{array}{l}0.62 \pm 0.7 \\
(p<0.05)\end{array}$ & 20 & 98.03 \\
\hline $\begin{array}{l}\text { Immunized with } \\
\text { adjuvant }\end{array}$ & 6 & 6 & $\begin{array}{c}153 \\
(25.5 \pm 12.75) \\
\end{array}$ & $0.43 \pm 0.48$ & 0 & 72.5 \\
\hline Positive control & 4 & 4 & $\begin{array}{c}372 \\
(93 \pm 4.05)\end{array}$ & $0.42 \pm 0.5$ & 0 & \\
\hline
\end{tabular}


tions 6-18), B (fractions 19-28), and C (fractions 29-32) were collected from Sephadex G-150. All these fractions were examined by IHT for heat shock protein 70 using monoclonal anti-heat shock protein 70 . Heat shock protein 70 was detected in peaks $A$ and $B$ in fractions 8 and 20-25.

\section{Immunization study}

Mice receiving hydatid antigens derived from protoscoleces exposed to $37^{\circ} \mathrm{C}$ (preparation 1) showed a relatively minimum resistance to infection with protection and reduction rates ranging from $0 \%$ to $25 \%$ and $77.69 \%$ to $98.38 \%$, respectively. The size of secondary hydatid cysts showed no significant difference ( $p>0.05$ ) in mice receiving $60 \mu \mathrm{g}$ of the antigen with the adjuvant and $90 \mu \mathrm{g}$ of the antigen without the adjuvant. In the other groups receiving preparation $1\left(37^{\circ} \mathrm{C}\right)$, the size of developed cysts was significantly reduced $(p<0.05, p<0.01)$ respectively than that developed in the positive control group and in the mice immunized with the adjuvant alone (Table 1).

Mice immunized with preparation $1\left(45^{\circ} \mathrm{C}\right)$ showed relatively moderate resistance to infection with protection and reduction rates ranging from $0 \%$ to $66.66 \%$ and $94.62 \%$ to $98.92 \%$, respectively. The number of developed cysts was significantly $(p<0.05)$ less than that developed in the positive control group and mice immunized with the adjuvant alone. The size of developed cysts was variable and showed significant difference in mice receiving 30 and $90 \mu \mathrm{g}$ of the antigen with the adjuvant $(p<0.01$ and $\mathrm{p}<0.05$, respectively) and $60 \mu \mathrm{g}$ of the antigen without the adju- vant $(p<0.01)$ in comparison with the size of cysts developed in the positive control group (Table 2).

In the other experimental groups immunized with preparation 2 $\left(45^{\circ} \mathrm{C}\right)$, the immunization protocol conferred higher protection and reduction rates, with absolute protection observed in mice immunized with 60 and $90 \mu \mathrm{g}$ of the antigen with the adjuvant. The size of developed cysts was also significantly reduced $(p<0.01)$ in all mice receiving preparation $2\left(45^{\circ} \mathrm{C}\right)$ in comparison with that developed in the positive control group and mice immunized with the adjuvant alone (Table 3).

Liver and renal function assessment is shown in Tables 4, 5, and 6 . Non-significant differences $(p>0.05)$ in biochemical parameters were observed between the immunized mice and negative control group.

The results of immunological parameters are shown in Table 7. There was a negative correlation between number of cysts and both immunological parameters, LTT $(r=-0.0695)$ and anti-hydatid antibody titers by IHT ( $r=0.1042)$.

\section{DISCUSSION}

Because the intermediate hosts for Echinococcus granulosus including humans show little or no natural resistance to infection with hydatid disease, many attempts have been made to stimulate the immune responses in murine models $(13,26,30-32)$ and sheep $(33,34)$ to develop immunity against hydatid infection. In this study, we found that the subcutaneous injection of mice with

Table 2. Reduction rate of secondary hydatid cysts, protection rate, number and size of cysts in mice immunized with hydatid antigens derived from protoscoleces exposed to $45 \mathrm{C}^{\circ}$ for 4 hours.

\begin{tabular}{|c|c|c|c|c|c|c|}
\hline $\begin{array}{l}\text { Experimental } \\
\text { groups }\end{array}$ & No. of mice & $\begin{array}{l}\text { No. of infected } \\
\text { mice }\end{array}$ & $\begin{array}{l}\text { No. of cysts } \\
\text { (Mean } \pm \text { SD) }\end{array}$ & $\begin{array}{l}\text { Mean of cyst } \\
\text { size } \pm S D(m m)\end{array}$ & $\begin{array}{l}\text { Protection } \\
\text { (\%) }\end{array}$ & $\begin{array}{l}\text { Reduction } \\
\text { of cysts (\%) }\end{array}$ \\
\hline $\begin{array}{l}\text { Immunized with } \\
30 \mu g \text { plus } \\
\text { adjuvant }\end{array}$ & 6 & 6 & $\begin{array}{c}30 \\
(5.0 \pm 3.3) \\
(p<0.05)\end{array}$ & $\begin{array}{l}0.26 \pm 0.19 \\
(p<0.01)\end{array}$ & 0 & 94.62 \\
\hline $\begin{array}{l}\text { Immunized with } \\
60 \mu g \text { plus } \\
\text { adjuvant }\end{array}$ & 6 & 4 & $\begin{array}{c}12 \\
(2.0 \pm 3.09) \\
(p<0.05)\end{array}$ & $\begin{array}{c}0.65 \pm 0.64 \\
\text { NS }\end{array}$ & 33.33 & 97.84 \\
\hline $\begin{array}{l}\text { Immunized with } \\
90 \mu g \text { plus } \\
\text { adjuvant }\end{array}$ & 4 & 2 & $\begin{array}{c}4 \\
(1 \pm 1.41) \\
(p<0.05)\end{array}$ & $\begin{array}{c}0.28 \pm 0.17 \\
(p<0.05)\end{array}$ & 50 & 98.92 \\
\hline $\begin{array}{l}\text { Immunized with } \\
30 \mu \mathrm{g}\end{array}$ & 6 & 3 & $\begin{array}{c}25 \\
(4.16 \pm 7.86) \\
(p<0.05)\end{array}$ & $\begin{array}{c}0.41 \pm 0.44 \\
\text { NS }\end{array}$ & 50 & 95.52 \\
\hline $\begin{array}{l}\text { Immunized with } \\
60 \mu \mathrm{g}\end{array}$ & 6 & 4 & $\begin{array}{c}20 \\
(3.33 \pm 3.72) \\
(p<0.05)\end{array}$ & $\begin{array}{c}0.21 \pm 0.15 \\
(p<0.01)\end{array}$ & 33.33 & 96.41 \\
\hline $\begin{array}{l}\text { Immunized with } \\
90 \mu \mathrm{g}\end{array}$ & 6 & 2 & $\begin{array}{c}7 \\
(1.16 \pm 2.4) \\
(p<0.05)\end{array}$ & $\begin{array}{c}0.4 \pm 0.42 \\
\text { NS }\end{array}$ & 66.66 & 98.75 \\
\hline $\begin{array}{l}\text { Immunized with } \\
\text { adjuvant }\end{array}$ & 6 & 6 & $\begin{array}{c}153 \\
(25.5 \pm 12.75)\end{array}$ & $0.43 \pm 0.48$ & 0 & 72.5 \\
\hline Positive control & 4 & 4 & $\begin{array}{c}372 \\
(93 \pm 40.05)\end{array}$ & $0.42 \pm 0.5$ & 0 & \\
\hline
\end{tabular}


Table 3. Reduction rate of secondary hydatid cysts, protection rate, nuber and size of cysts in mice immunized with partially purified hydatid antigens, containing heat shock protein 70 , derived from protoscoleces exposed to $45 \mathrm{C}^{\circ}$ for 4 hours.

\begin{tabular}{|c|c|c|c|c|c|c|}
\hline $\begin{array}{l}\text { Experimental } \\
\text { groups }\end{array}$ & No. of mice & $\begin{array}{l}\text { No. of infected } \\
\text { mice }\end{array}$ & $\begin{array}{l}\text { No. of cysts } \\
\text { (Mean } \pm \text { SD) }\end{array}$ & $\begin{array}{l}\text { Mean of cyst } \\
\text { size } \pm S D(m m)\end{array}$ & $\begin{array}{c}\text { Protection } \\
(\%)\end{array}$ & $\begin{array}{l}\text { Reduction } \\
\text { of cysts(\%) }\end{array}$ \\
\hline $\begin{array}{l}\text { Immunized with } \\
30 \mu g \text { plus } \\
\text { adjuvant }\end{array}$ & 5 & 1 & $\begin{array}{c}3 \\
(0.6 \pm 1.34) \\
(p<0.05)\end{array}$ & $\begin{array}{c}0.1 \pm 0 \\
(p<0.01)\end{array}$ & 80 & 99.35 \\
\hline $\begin{array}{l}\text { Immunized with } \\
60 \mu \mathrm{g} \text { plus } \\
\text { adjuvant }\end{array}$ & 6 & 0 & $\begin{array}{c}0 \\
(p<0.05)\end{array}$ & $\begin{array}{c}0 \\
(p<0.01)\end{array}$ & 100 & 100 \\
\hline $\begin{array}{l}\text { Immunized with } \\
90 \mu \mathrm{g} \text { plus } \\
\text { adjuvant }\end{array}$ & 6 & 0 & $\begin{array}{c}0 \\
(p<0.05)\end{array}$ & $\begin{array}{c}0 \\
(p<0.01)\end{array}$ & 100 & 100 \\
\hline $\begin{array}{l}\text { Immunized with } \\
30 \mu \mathrm{g}\end{array}$ & 5 & 4 & $\begin{array}{c}11 \\
(2.2 \pm 2.16) \\
(p<0.05)\end{array}$ & $\begin{array}{c}0.15 \pm 0.07 \\
(p<0.01)\end{array}$ & 20 & 97.63 \\
\hline $\begin{array}{l}\text { Immunized with } \\
60 \mu \mathrm{g}\end{array}$ & 6 & 2 & $\begin{array}{c}6 \\
(1.0 \pm 1.55) \\
(p<0.05)\end{array}$ & $\begin{array}{c}0.15 \pm 0.08 \\
(p<0.01)\end{array}$ & 66.66 & 98.92 \\
\hline $\begin{array}{l}\text { Immunized with } \\
90 \mu \mathrm{g}\end{array}$ & 4 & 3 & $\begin{array}{c}10 \\
(2.5 \pm 1.73) \\
(p<0.05)\end{array}$ & $\begin{array}{l}0.17 \pm 0.1 \\
(p<0.01)\end{array}$ & 25 & 97.31 \\
\hline $\begin{array}{l}\text { Immunized with } \\
\text { adjuvant }\end{array}$ & 6 & 6 & $\begin{array}{c}153 \\
(25.5 \pm 12.75) \\
\end{array}$ & $0.43 \pm 0.48$ & 0 & 72.5 \\
\hline Positive control & 4 & 4 & $\begin{array}{c}372 \\
(93 \pm 40.05)\end{array}$ & $0.42 \pm 0.5$ & 0 & \\
\hline
\end{tabular}

Table 4. Biochemical parameters in the sera of mice immunized with hydatid antigens derived from protoscoleces exposed to $37 \mathrm{C}^{\circ}$ for 4 hours.

\begin{tabular}{|c|c|c|c|}
\hline Experimental groups & ALT activity (IU/ml) & AST activity (IU/ml) & Blood urea (mg/dl) \\
\hline $\begin{array}{l}\text { Immunized with } \\
30 \mu \mathrm{g} \text { plus adjuvant }\end{array}$ & $\begin{array}{c}38.23 \pm 15.1 \\
\text { NS }\end{array}$ & $\begin{array}{c}67.21 \pm 19.5 \\
\text { NS }\end{array}$ & $\begin{array}{c}40.47 \pm 5.19 \\
\text { NS }\end{array}$ \\
\hline $\begin{array}{l}\text { Immunized with } \\
60 \mu \mathrm{g} \text { plus adjuvant }\end{array}$ & $\begin{array}{l}41.55 \pm 0.49 \\
\text { NS }\end{array}$ & $\begin{array}{c}79.97 \pm 6.89 \\
\text { NS }\end{array}$ & $\begin{array}{l}40.47 \pm 5.19 \\
\text { NS }\end{array}$ \\
\hline $\begin{array}{l}\text { Immunized with } \\
90 \mu \mathrm{g} \text { plus adjuvant }\end{array}$ & $\begin{array}{c}25.49 \pm 8.4 \\
\text { NS }\end{array}$ & $\begin{array}{c}74.73 \pm 28.6 \\
\text { NS }\end{array}$ & $\begin{array}{c}28.86 \pm 8.28 \\
\text { NS }\end{array}$ \\
\hline Immunized with $30 \mu \mathrm{g}$ & $\begin{array}{c}40.16 \pm 23.2 \\
\text { NS }\end{array}$ & $\begin{array}{c}76.29 \pm 13.1 \\
\text { NS }\end{array}$ & $\begin{array}{c}33.5 \pm 10.14 \\
\text { NS }\end{array}$ \\
\hline Immunized with $60 \mu \mathrm{g}$ & $\begin{array}{c}22.35 \pm 1.97 \\
\text { NS }\end{array}$ & $\begin{array}{l}45.75 \pm 4.9 \\
\text { NS }\end{array}$ & $\begin{array}{l}33.9 \pm 13.34 \\
\text { NS }\end{array}$ \\
\hline Immunized with $90 \mu \mathrm{g}$ & $\begin{array}{c}40.86 \pm 2.47 \\
\text { NS }\end{array}$ & $\begin{array}{c}78.22 \pm 4.9 \\
\text { NS }\end{array}$ & $\begin{array}{c}25.99 \pm 3.06 \\
\text { NS }\end{array}$ \\
\hline Immunized with adjuvant & $46.79 \pm 0.49$ & $83.63 \pm 1.23$ & $33.54 \pm 7.22$ \\
\hline Negative control & $39.89 \pm 5.2$ & $83.28 \pm 8.3$ & $31.2 \pm 2.6$ \\
\hline
\end{tabular}

hydatid antigens derived from protoscoleces exposed to $37^{\circ} \mathrm{C}$, which is the normal physiological temperature of the hosts, conferred no significant protection in mice challenged with 2000 viable protoscoleces. This might be due to the fact that the protoscolex extract solution contains a mixture of T-independent and-dependent antigens that can stimulate the host immune system to produce high levels of both protective and non-protective immunoglobulins $(35,36)$. Baz et al. (37) have shown that protoscolex somatic antigens induce the production of all classes and subclasses of immunoglobulins, except lgG3, in CD4+depleted mice. On the other hand, Dematteis et al. (27) have shown that the sera of mice experimentally infected with viable 
Table 5. Biochemical parameters in the sera of mice immunized with hydatid antigens derived from protoscoleces exposed to $45 \mathrm{C}^{\circ}$ for 4 hours.

\begin{tabular}{|c|c|c|c|}
\hline Experimental groups & ALT activity (IU/ml) & AST activity (IU/ml) & Blood urea (mg/dl) \\
\hline $\begin{array}{l}\text { Immunized with } \\
30 \mu \mathrm{g} \text { plus adjuvant }\end{array}$ & $\begin{array}{c}51.21 \pm 0.98 \\
\text { NS }\end{array}$ & $\begin{array}{c}92.88 \pm 25.2 \\
\text { NS }\end{array}$ & $\begin{array}{l}34.22 \pm 4.7 \\
\text { NS }\end{array}$ \\
\hline $\begin{array}{l}\text { Immunized with } \\
60 \mu \mathrm{g} \text { plus adjuvant }\end{array}$ & $\begin{array}{l}49.93 \pm 6.4 \\
\text { NS }\end{array}$ & $\begin{array}{l}84.86 \pm 10.9 \\
\text { NS }\end{array}$ & $\begin{array}{c}35.34 \pm 12.7 \\
\text { NS }\end{array}$ \\
\hline $\begin{array}{l}\text { Immunized with } \\
90 \mu \mathrm{g} \text { plus adjuvant }\end{array}$ & $\begin{array}{l}39.98 \pm 7.2 \\
\text { NS }\end{array}$ & $\begin{array}{l}81.36 \pm 0.5 \\
\text { NS }\end{array}$ & $\begin{array}{l}37.44 \pm 8.3 \\
\text { NS }\end{array}$ \\
\hline Immunized with $30 \mu \mathrm{g}$ & $\begin{array}{c}39.43 \pm 1.9 \\
\text { NS }\end{array}$ & $\begin{array}{l}84.68 \pm 4.7 \\
\text { NS }\end{array}$ & $\begin{array}{l}39.3 \pm 20.5 \\
\text { NS }\end{array}$ \\
\hline Immunized with $60 \mu \mathrm{g}$ & $\begin{array}{l}47.83 \pm 1.5 \\
\text { NS }\end{array}$ & $\begin{array}{l}68.1 \pm 4.9 \\
\text { NS }\end{array}$ & $\begin{array}{c}47.79 \pm 25.5 \\
\text { NS }\end{array}$ \\
\hline Immunized with $90 \mu \mathrm{g}$ & $\begin{array}{c}33.69 \pm 10.6 \\
\text { NS }\end{array}$ & $\begin{array}{c}79.1 \pm 2.7 \\
\text { NS }\end{array}$ & $\begin{array}{c}38.62 \pm 11.5 \\
\text { NS }\end{array}$ \\
\hline Immunized with adjuvant & $46.79 \pm 0.49$ & $83.63 \pm 1.23$ & $33.54 \pm 7.22$ \\
\hline Negative control & $39.89 \pm 5.2$ & $83.28 \pm 8.3$ & $31.2 \pm 2.6$ \\
\hline
\end{tabular}

Table 6. Biochemical parameters in the sera of mice immunized with hydatid antigens derived from protoscoleces exposed to $45 \mathrm{C}^{\circ}$ for 4 hours

\begin{tabular}{|c|c|c|c|}
\hline Experimental groups & ALT activity (IU/ml) & AST activity (IU/ml) & Blood urea (mg/dl) \\
\hline $\begin{array}{l}\text { Immunized with } \\
30 \mu \mathrm{g} \text { plus adjuvant }\end{array}$ & $\begin{array}{c}46.82 \pm 10.3 \\
\text { NS }\end{array}$ & $\begin{array}{l}86.1 \pm 2.2 \\
\text { NS }\end{array}$ & $\begin{array}{l}30.0 \pm 10.4 \\
\text { NS }\end{array}$ \\
\hline $\begin{array}{l}\text { Immunized with } \\
60 \mu \mathrm{g} \text { plus adjuvant }\end{array}$ & $\begin{array}{l}38.58 \pm 14.5 \\
\text { NS }\end{array}$ & $\begin{array}{c}86.42 \pm 13.5 \\
\text { NS }\end{array}$ & $\begin{array}{l}28.65 \pm 6.1 \\
\text { NS }\end{array}$ \\
\hline $\begin{array}{l}\text { Immunized with } \\
90 \mu \mathrm{g} \text { plus adjuvant }\end{array}$ & $\begin{array}{c}27.93 \pm 0.99 \\
\text { NS }\end{array}$ & $\begin{array}{l}76.47 \pm 1.5 \\
\text { NS }\end{array}$ & $\begin{array}{c}33.2 \pm 3.9 \\
\text { NS }\end{array}$ \\
\hline Immunized with $30 \mu \mathrm{g}$ & $\begin{array}{c}41.38 \pm 10.1 \\
\text { NS }\end{array}$ & $\begin{array}{c}81.71 \pm 6.9 \\
\text { NS }\end{array}$ & $\begin{array}{c}34.38 \pm 6.75 \\
\text { NS }\end{array}$ \\
\hline Immunized with $60 \mu \mathrm{g}$ & $\begin{array}{c}35.42 \pm 5.3 \\
\text { NS }\end{array}$ & $\begin{array}{c}81.19 \pm 3.2 \\
\text { NS }\end{array}$ & $\begin{array}{l}32.42 \pm 0.7 \\
\text { NS }\end{array}$ \\
\hline Immunized with $90 \mu \mathrm{g}$ & $\begin{array}{l}55.68 \pm 2.2 \\
\text { NS }\end{array}$ & $\begin{array}{c}71.1 \pm 15.5 \\
\text { NS }\end{array}$ & $\begin{array}{l}32.7 \pm 1.4 \\
\text { NS }\end{array}$ \\
\hline Immunized with adjuvant & $46.79 \pm 0.49$ & $83.63 \pm 1.23$ & $33.54 \pm 7.22$ \\
\hline Negative control & $39.89 \pm 5.2$ & $83.28 \pm 8.3$ & $31.2 \pm 2.6$ \\
\hline
\end{tabular}

protoscoleces contain significant levels of immunoglobulins specific to the carbohydrate epitopes of protoscolex somatic antigens that play a key role in the activation of the non-protective $\mathrm{TH} 2$ arm of the immune response. Therefore, in spite of the production of anti-hydatid antibodies and the relatively high percentages of lymphocyte transformation in mice immunized with preparation $1\left(37^{\circ} \mathrm{C}\right)$, the animals showed low protection rates because these immune elements may be non- protective.

This study revealed that mice immunized with 60 and $90 \mu \mathrm{g}$ of purified heat-shocked protoscolex antigens combined with the adjuvant showed a $100 \%$ protection rate. Such high rates of protection and reduction in these groups may be explained by the fact that protoscolex cells, like other eukaryotic cells, are responding to elevated temperature by increasing the synthesis of various proteins including heat shock proteins $(38,39)$. The most striking example of this is Escherichia coli heat shock proteins, which account for $1.6 \%$ of the total cell protein under normal growth conditions and can accumulate to $15 \%$ of the total protein after heat shock (38). The efficacy of hydatid antigens derived from protoscoleces exposed to heat shock is related to the synthesis of various proteins and heat shock proteins. These proteins have been shown to induce the synthesis of pro-inflammatory cytokines such as TNF alpha, interleukin-1, interleukin-6, and interleukin-12; the release of nitric oxide and C-C chemokines by macrophages, monocytes, and dendritic 
Table 7. Lymphocyte transformation test and anti-hydatid antibody titer by indirect hemagglutination test results in experimental mice

\begin{tabular}{|c|c|c|c|}
\hline & $\begin{array}{l}\text { Experimental } \\
\text { groups }\end{array}$ & $\begin{array}{c}\text { LTT } \\
\text { percent }\end{array}$ & $\begin{array}{l}\text { IHT } \\
\text { titer }\end{array}$ \\
\hline \multirow{6}{*}{$\begin{array}{l}\text { Immunized with } \\
\text { preparation } \\
1,37^{\circ} \mathrm{C} \text { (crude) }\end{array}$} & $30 \mu \mathrm{g}$ with adjuvant & 15.035 & 4 \\
\hline & $60 \mu \mathrm{g}$ with adjuvant & 16.88 & 8 \\
\hline & $90 \mu \mathrm{g}$ with adjuvant & 11.57 & 8 \\
\hline & $30 \mu \mathrm{g}$ without adjuvant & 19.75 & 8 \\
\hline & $60 \mu \mathrm{g}$ without adjuvant & 12.43 & 8 \\
\hline & $90 \mu \mathrm{g}$ without adjuvant & 8.97 & 8 \\
\hline \multirow{6}{*}{$\begin{array}{l}\text { Immunized with } \\
\text { preparation } \\
1,45^{\circ} \mathrm{C} \text { (crude) }\end{array}$} & $30 \mu \mathrm{g}$ with adjuvant & 21.05 & 16 \\
\hline & $60 \mu \mathrm{g}$ with adjuvant & 14.69 & 8 \\
\hline & $90 \mu \mathrm{g}$ with adjuvant & 9.76 & 8 \\
\hline & $30 \mu \mathrm{g}$ without adjuvant & 24.61 & 16 \\
\hline & $60 \mu \mathrm{g}$ without adjuvant & 23.83 & 4 \\
\hline & $90 \mu \mathrm{g}$ without adjuvant & 10.99 & 4 \\
\hline \multirow{6}{*}{$\begin{array}{l}\text { Immunized with } \\
\text { preparation } \\
2,45^{\circ} \mathrm{C} \text { (purified) }\end{array}$} & $30 \mu \mathrm{g}$ with adjuvant & 24.51 & 8 \\
\hline & $60 \mu \mathrm{g}$ with adjuvant & 25.71 & 4 \\
\hline & $90 \mu \mathrm{g}$ with adjuvant & 18.39 & 4 \\
\hline & $30 \mu \mathrm{g}$ without adjuvant & 24.14 & 8 \\
\hline & $60 \mu \mathrm{g}$ without adjuvant & 24.96 & 4 \\
\hline & $90 \mu \mathrm{g}$ without adjuvant & 4.41 & 4 \\
\hline $\begin{array}{l}\text { Immunized with } \\
\text { adjuvant alone }\end{array}$ & & 4.9 & Negative \\
\hline Negative control & & 4.75 & Negative \\
\hline
\end{tabular}

cells (40); and the maturation of dendritic cells through the induction of the upregulation of $\mathrm{MHC} \mathrm{I}, \mathrm{MHC} \mathrm{II,CD86,} \mathrm{and}$ CD40 (18). Another important role of heat shock protein 70 is that it acts as a CD40 ligand and binds to CD40 on dendritic cells and macrophages, inducing the synthesis of interleukin-12, which stimulates the development of the TH1 subset of lymphocytes and enhances TH1, CD8+ TC, and natural killer cells to produce gamma interferon. Gamma interferon stimulates the protective mechanisms of the immune system by inducing class switching into IgG1 and IgG3; upregulating $\mathrm{MHC} \mathrm{I,} \mathrm{MHC} \mathrm{II,} \mathrm{and}$ co-stimulatory molecules on antigen-presenting cells; and enhancing the microbicidal activity of phagocytes $(41,42)$.

Mice receiving the purified hydatid antigen containing heat shock protein 70 showed more resistance than those immunized with crude heat-shocked protoscolex antigens, which may be due to the presence of many immunomodulators such as T-independent antigens and major specific hydatid antigens such as antigen $B(120-160 \mathrm{KDa})$, which is an important immunomodulator and potent activator of the non-protective $\mathrm{TH} 2 \mathrm{arm}$ of the immune response (43). High levels of this antigen, because of its relatively large size, were removed during gel fil- tration, and only those hydatid antigens, including antigen 5, with a molecular weight of approximately $70 \mathrm{KDa}$ were eluted in same fractions with heat shock protein 70 .

This study suggests that incubation of viable protoscoleces in $45^{\circ} \mathrm{C}$ for $4 \mathrm{~h}$ induces the overexpression of various antigens including heat shock proteins, heat shock protein 70 in particular, which can be used as a vaccine candidate for protection against hydatid infection in mice. Designing experiments to study the efficacy of antigens prepared from heat-shocked protoscoleces in the protection of other hosts such as sheep against challenge infection with viable eggs or onchospheres of E. granulosus is recommended.

\section{Ethics Committee Approval: N/A}

\section{Informed Consent: N/A}

Peer-review: Externally peer-reviewed.

Author Contributions: Consept - H.H., T.S.A.H., H.M.A.S.; Design - H.H., T.S.A.H., H.M.A.S.; Supervision - H.H., T.S.A.H.; Funding - H.H., T.S.A.H., H.M.A.S.; Materials - H.H., T.S.A.H., H.M.A.S.; Data Collection and/or Processing - H.H., T.S.A.H., H.M.A.S.; Analysis and/or Interpretation H.H., T.S.A.H., H.M.A.S.; Literature Review - H.H., T.S.A.H., H.M.A.S.; Writer - H.H., T.S.A.H., H.M.A.S.; Critical Review - H.H., T.S.A.H., H.M.A.S.

Acknowledgments: We would like to thank the veterinarians and meat inspection staff at the slaughter house in Erbil for their help in collecting hydatid cyst samples from slaughtered sheep and the manager and workers of the animal house of the College of Medicine, Hawler Medical University, for their help in keeping and breeding the experimental mice.

Conflict of Interest: No conflict of interest was declared by the authors.

Financial Disclosure: The authors declared that this study has received no financial support.

Etik Komite Onayı: Gerek yoktur.

Hasta Onamı: Gerek yoktur.

Hakem Değerlendirmesi: Dış Bağımsız.

Yazar Katkıları: Fikir - Hussain F. Hassan., Tariq S. AL-Hadithi., Hadi M Al-Sakee.; Tasarım - Hussain F. Hassan., Tariq S. AL-Hadithi., Hadi M Al-Sakee.; Denetleme - Hussain F. Hassan., Tariq S. AL-Hadithi; Kaynaklar - Hussain F. Hassan., Tariq S. AL-Hadithi., Hadi M Al-Sakee.; Malzemeler - Hussain F. Hassan., Tariq S. AL-Hadithi., Hadi M Al-Sakee.; Veri Toplanması ve/veya işlemesi - Hussain F. Hassan., Tariq S. AL-Hadithi., Hadi M Al-Sakee.; Analiz ve/veya Yorum - Hussain F. Hassan .,Tariq S. AL-Hadithi., Hadi M Al-Sakee.; Literatür taraması - Hussain F. Hassan., Tariq S. AL-Hadithi., Hadi M Al-Sakee.; Yazıyı Yazan - x.x Hussain F. Hassan., Tariq S. AL-Hadithi., Hadi M Al-Sakee.; Eleştirel İnceleme - x.x Hussain F. Hassan., Tariq S. AL-Hadithi., Hadi M Al-Sakee.

Çıkar Çatışması: Yazarlar herhangi bir çıkar çatışması bildirmemişlerdir.

Finansal Destek: Yazarlar bu çalışma için finansal destek almadıklarını beyan etmişlerdir.

\section{REFERENCES}

1. Matossian RM, Rickard MD, Smyth JD. Hydatidosis: a global problem of increasing importance. Bull World Health Organ 1977; 55: 499-507.

2. Macpherson $C N$, Craig PS, Romig T, Zeyhle $E$, Watschinger $H$. Observations on human echinococcosis (hydatidosis) and evaluati- 
on of transmission factors in the Maasai of northern Tanzania. Ann Trop Med Parasitol 1989 Oct; 83: 489-97.

3. Craig PS, Deshan L, Macpherson CN, Dazhong S, Reynolds D, Barnish G, Gottstein B, Zhirong W. A large focus of alveolar echinococcosis in central China. Lancet 1992 Oct 3; 340: 826-31. [CrossRef]

4. el-On J, Khaleel E, Malsha Y, Nahmias, J Schantz P, Sneir R, Ben-Ismail R, Furth M, Hoida G. Echinococcus granulosus: a sero-epidemiological survey in northern Israel using an enzyme-linked immunosorbent assay. Trans R Soc Trop Med Hyg. 1997; 91: 529-32. [CrossRef]

5. Moro PL, McDonald J, Gilman RH, Silva B, Verastegui M, Malqui V, Lescano G, Falcon N, Montes G, Bazalar H. Epidemiology of Echinococcus granulosus infection in the central Peruvian Andes. Bull World Health Organ 1997; 75: 553-61.

6. Darani HY, Avijgan M, Karimi K, Manouchehri K, Masood J. Seroepidemiology of hydatid diseas in Chahar mahal va Bakhtiari province, Iran. Iran J Pub Health 2003; 32: 31-3.

7. Al-Jeboori T. Hydatid disease: a study of the records of the Medical City Hospital. J Fac Med Baghdad 1976; 18: 64-75.

8. Mahmoud SS, Al-Janab BM. Hydatid disease in children and youths in Mosul, Iraq. Ann Trop Med Parasitol 1983; 77: 327-8.

9. Al-Autabi JRZ. Hydatid disease: a retrospective study of three hospitals in Baghdad during 1994-1999. J Fac Med Baghdad 2002; 44: 514-21.

10. Saeed IS. Immunization of mice against Echinococcus granulosus by using protoscoleces exposed to ultraviolet irradiation. MSc thesis. Salahaddin University, Iraq; 1988

11. Al- Masudi HR. Effect of ultraviolet irradiation and gamma ray on the viability of Echinococcus granulosus protoscoleces. MSc thesis. Baghdad University, Iraq; 1989

12. Al-Aubaidy AEM. Protection of balb/c mice aginst hydatid cyst infection using antigens extracted from hydatid fluid and protoscoleces of Echinococcus granulosus. MSc thesis. Al-Mustansyria University, Iraq; 1996.

13. Al-Azzawy AA. Comparative study for protection of balb/c mice and white hamster against hydatid cysts using excretory/secretory antigen of protoscoleces and hydatid fluid antigens. MSc thesis. Baghdad University, Iraq; 1999

14. Todryk S, Melcher AA, Hardwick N, Linardakis E, Bateman A, Colombo MP, Stoppacciaro A, Vile RG. Heat shock protein 70 induced during tumor cell killing induces Th1 cytokines and targets immature dendritic cell precursors to enhance antigen uptake. J Immunol 1999; 163: 1398-408.

15. Deepe GS Jr, Gibbons RS. Cellular and molecular regulation of vaccination with heat shock protein 60 from Histoplasma capsulatum. Infect Immun 2002; 70: 3759-67. [CrossRef]

16. Li Z, Qiao Y, Liu B, Srivastava P. Heat shock protein 70-based vaccine stimulates both innate and adaptive immunity against chronic myeloid leukemia. ASCO Annual Proceedings. J Clinic Oncol 2004; 22: Supplement. Abstract Number 2515.

17. Liso A, Benedetti R, Faqioli M, Mariano A, Falini B: Modulatory effects of mycobacterial heat-shock protein 70 in DNA vaccination against lymphoma. Haematologica 2005; 90: 60-5.

18. Ye Z, Gan YH. Flagellin contamination of recombinant heat shock protein 70 is responsible for its activity on T cells. J Biol Chem 2006; 282: 4479-84. [CrossRef]

19. Sun Y, MacRae TH. The small heat shock proteins and their role in human disease. FEBS J 2005; 272: 2613-27. [CrossRef]

20. Li C, Lee J, Guy Ko Y, Kim J, Seo J. Heat shock protein 70 inhibits apoptosis downstream of cytochrome $c$ release and upstream of caspase-3 activation. J Biol Chem 2000; 275: 25665-71. [CrossRef]

21. Martinez J, Serrano JP, Bodega G, Casado N, Caabeiro FR. Heat shock proteins HSP70 and HSP60 in Echinococcus granulosus protoscolices. Folia Parasitol (Praha) 1999, 46: 76-8.

22. Seyyedi MA, Farahnak A, Jalali M, Rokni MB. Study on glutathione s-transferase (GST) inhibition assay by triclabendazole I: protoscoleces (hydatid cyst; Echinococcus granulosus) and sheep liver tissue. Iranian J Publ Health 2005; 34: 38-46.
23. Holtzhauer $\mathrm{M}$, editor. Basic methods for the biochemical lab. Berlin: Springer; 2006

24. Parija SC, Ananthakrishnan N. Evaluation of stabilised cells in the indirect haemagglutination tests for echinococcosis. J Med Microbiol 1985; 19: 95-8. [CrossRef]

25. Lowry OH, Rosebrough NJ, Farr AL, Randall RJ. Protein measurement with the folin phenol reagent. J Biol Chem 1951; 193: 265-75.

26. Hashemitabar GR, Razmi GR, Naghibi A. Protective immunity in mice with whole body of E. granulosus. Iranian Biomed J 2006; 10: 51-5.

27. Dematteis S, Pirotto F, Maques J, Nieto A, Orn A, Baz A. Modulation of the cellular immune response by a carbohydrate rich fraction from Echinococcus granulosus protoscoleces in infected or immunized Balb/c mice. Parasite Immunol 2001; 23: 1-9. [CrossRef]

28. Shubber EK, AL-Allak BMA. Spontaneous chromosomal aberration and SCE in human lymphocyte. I: effect of culture condition. Nucleus 1989; 29: 92-8.

29. Piacenza L, Acosta D, Basmadjian I, Dalton J, Carmona C. Vaccination with cathepsin $L$ proteinases and with leucine aminopeptidase induces high levels of protection against fascioliasis in sheep. Infect Immun 1999; 67: 1954-61

30. Molan A, Saeed I: Protection of mice against Echinococas granulosus by previous inoculation with protoscoleces exposed to ultra violet irradiation. Jpn J Parasitol 1988; 37: 203-8.

31. Resen FA. Studying the possibility of attenuation of protoscoleces of Echinococcus granulosus by laser beam. MSc thesis. Baghdad University, Iraq; 1994.

32. Baz A, Hernandez A, Dematteis S, Carol H, Nieto A. Idiotypic modulation of the antibody response of mice to $E$. granulosus antigens. Immunology 1995; 87: 350- 4.

33. Woollard DJ, Gauci CG, Heath DD, Lightowlers MW. Epitope specificities and antibody responses to the EG95 hydatid vaccine. Parasite Immunol 1998; 20: 535-40. [CrossRef]

34. Zhang W, Li J, You H, Zhang Z, Turson G, Loukas A, McManus DP. Short report: E.granulosus from Xinjiang, PR China: cDNAS encoding the EG95 vaccine antigen are expressed in different life cycle stages and are conserved in the oncosphere. Am J Trop Med Hyg 2003; 68: 40-3.

35. Zhang W, Li J, McManus DP. Concepts in immunology and diagnosis of hydatid disease. Clin Microbiol Rev 2003; 16: 18-36. [CrossRef]

36. Ortona E, Margutti P, Delunardo F, Vaccari S, Rigano R, Profumo E, et al. Molecular and immunological characterization of the C-terminal region of a new Echinococcus granulosus heat shock protein 70. Parasite Immunol 2003; 25: 119-26. [CrossRef]

37. Baz A, Richieri A, Puglia A, Nieto A, Dematteis S. Antibody response in CD4-depleted mice after immunization or during early infection with E. granulosus. Parasite Immunol 1999; 21: 141-50. [CrossRef]

38. Young RA, Elliot TJ. Stress proteins, infection and immune surveillance. Cell 1989; 59: 5-8. [CrossRef]

39. Schlesinger MJ. Heat shock proteins. J Biol Chem 1990; 265: 12111-14.

40. Tsan MF, Gao B. Cytokine function of heat shock proteins. Am J Physiol Cell Physiol 2004; 286: 739-44. [CrossRef]

41. Abbas AK, Lichtman AH, editors. Cellular and molecular immunology. Fifth Edition. Philadelphia: Saunders, an imprint of Elsevier Science; 2003

42. Wang Y, Whittall T, McGowan E, Younson J, Kelly C, Bergmeier LA et al. Identification of stimulating and inhibitory epitopes within the heat shock protein 70 molecule that modulate cytokine production and maturation of dendritic cells. J Immunol 2005; 174: 3306-16. [CrossRef]

43 Rigano R, Profumo E, Bruschi F, Carulli G, Azzara A, lopplo S, et al. Modulation of human immune response by Echinococcus granulosus antigen $B$ and its possible role in evading host defenses. Infect Immun 2001; 69: 288-96. [CrossRef] 